\title{
Role Board Games as a Tool for Reconfiguration of Innovation Factors in Forest Ecosystem Services

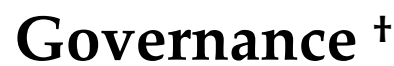

\author{
Martin Špaček 1,**, Tatiana Kluvánková ${ }^{2}$, Veronika Gežík ${ }^{2}$, Viera Baštáková ${ }^{2}$, Iveta Štecová ${ }^{2}$ and \\ Jiř́ Louda ${ }^{3}$ \\ 1 CETIP-Centre for Transdisciplinary Studies and Jan Evangelista Purkyne University in Usti nad Labem, \\ Ústí nad Labem, Czechia \\ 2 CETIP-Centre for Transdisciplinary Studies and Institute of Forest Ecology, Slovak Academy of Sciences, \\ Bratislava, Slovakia; tana@cetip.sk (T.K.); veronikagezik@gmail.com (V.G.); bastakova@ife.sk (V.B.); \\ stecova@ife.sk (I.Š.) \\ 3 IREAS, Institute for Structural Policy and Jan Evangelista Purkyne University in Usti nad Labem, Ústí nad \\ Labem, Czechia; louda@ieep.cz \\ * Correspondence: spacek@e-academia.eu \\ † Presented at TERRAenVISION 2019, Barcelona, 2-7 September 2019.
}

Published: 8 November 2019

\begin{abstract}
Forest ecosystem services (FES) are considered as public or common goods facing diverging individual and societal interests affecting the quality of ecosystems and well-being of the communities. This may result in overuse, degradation or unsustainable behaviour, as well as it can create also barriers for cooperation, economic profit and innovative business initiatives. The paper introduces the methodological approach which is applied within six different innovation regions (conceptualised as social-ecological systems) within the InnoForESt H2020 project. Each region uses innovative approaches in governance of FES and payments schemes. They are situated in Austria, the Czechia and Slovakia, Finland, Germany, Italy and Finland. All are characterised by manifold, sometimes diverging, FES, such as timber, recreation, regulation services or education. In order to get a better understanding of the role and the impact of key innovation factors for the regions, we have designed a behavioural [lab] experiment in the form of a Role board game (RBG). The proposed experimental game builds on Cardenas et al. (2013) and Castillo et al. (2011) as an interactive agentbased model arranging for repeated interaction and learning in real-world situations. It contributes to testing the effectiveness of incentives provision for the sustainable production of FES and the acceptance of such an intervention by FES communities (Kluvankova et al., in press). The game enables the adaptation to the specifics of each innovation region but at the same time it keeps the same internal experimental mechanism which will enable the comparison across the regions. The main question to be addressed by the RBG is: How to create conditions to enable innovations in forest management/governance for sustainable use and well-being in innovation regions under the diverging interest of FES users? We plan to test combinations of key innovation factors as preferred future scenario for sustainable FES provisions in regions, including fundamental policy interventions (e.g. strict regulation vs. payments for ecosystem services scheme), business incentives and external risk factors. RBG will allow testing stakeholders' specific behaviour for resource use, and innovation activities, to create economic incentive, knowledge and social value. We argue that this will help to set conditions for successful development of policy and business innovations in innovations regions and to foster collaboration on FES provision for sustainability among stakeholders in a long term.
\end{abstract}

Keywords: Role Board Games; forest ecosystem services; common goods; payments for ecosystem services; behavioral experiment 
Acknowledgments: The research leading to these results has received funding from the European Union Horizon 2020 under the Grant Agreement number 763899, InnoForESt project, within the Innovation Action.

(C) 2019 by the authors. Licensee MDPI, Basel, Switzerland. This article is an open access article distributed under the terms and conditions of the Creative Commons Attribution (CC BY) license (http://creativecommons.org/licenses/by/4.0/). 